\title{
FAKTOR-FAKTOR YANG MEMPENGARUHI KONSUMEN DALAM PEMBELIAN MAKANAN JAJANAN TRADISIONAL DI KELURAHAN PERDAMEAN
}

\author{
Zuriani Ritonga \\ Dosen Tetap Sekolah Tinggi Ilmu Ekonomi (STIE) Labuhanbatu
}

\begin{abstract}
ABSTRAK
Penelitian ini bertujuan untuk mengetahui: (1) pengaruh harga pembelian makanan ringan tradisional di Kelurahan Perdamean dan (2) pengaruh lokasi pembelian makanan ringan tradisional di Kelurahan Perdamean. Penelitian ini meliputi penelitian survey dengan pendekatan kuantitatif. Populasi dalam penelitian ini adalah masyarakat kelurahan Perdamean. Berdasarkan hasil perhitungan jumlah sampel yang ditentukan digunakan sebanyak 98 orang. Teknik pengumpulan data menggunakan kuesioner yang telah diuji validitas dan reliabilitasnya. Teknik analisis data yang digunakan adalah regresi linier berganda. Hasil penelitian menunjukkan bahwa: (1) harga suatu pengaruh signifikan terhadap pembelian makanan ringan tradisional di Kelurahan Perdamean, terbukti dari nilai signifikansi 0,001 <0,05 dan koefisien regresi sebesar 0,329, (2) lokasi. Pengaruh signifikan terhadap pembelian makanan ringan tradisional di Kelurahan Perdamean, terbukti signifikansi 0,000<0,05 dan koefisien regresi 0,493.
\end{abstract}

Kata Kunci: Harga, Lokasi, Keputusan Pembelian.

\section{PENDAHULUAN}

Makanan adalah kebutuhan pokok setiap insan manusia. Dalam teoriHierarki Kebutuhan Maslow menyebutkan bahwa makanan merupakan salah satukebutuhan fisiologis manusia. Sebagai kebutuhan dasar, makananmenjadi sangat penting bagi manusia sehingga dalam aspek bisnis pun makananmenjadi pilihan untuk dijadikan obyek bisnis. Tidak heran banyak individu yangtertarik dan menganggap bisnis kuliner sebagai jenis bisnis yang memiliki prospekyang baik, terbukti dari makin banyaknya rumah makan dan sentra kuliner diberbagai sudut kota. Selain sebagai kebutuhan dasar, kegiatan makan di luarrumah juga sudah menjadi gaya hidup masyarakat Indonesia, ditambah puladengan meningkatnya daya beli serta pendapatan masyarakat.

Meski demikian, dalam memulai sebuah bisnis para pelaku bisnis harusmemperhatikan perilaku konsumen. Perilaku konsumen adalah kebiasaanmembeli atau pola-pola perilaku konsumsi masyarakat dalam kelompok-kelompokyang umum atau yang khusus.

Pada dasarnya setiap kegiatan bisnis selalu berorientasi pada keuntungan,sehingga strategi-strategi yang dirancang tersebut diharapkan dapat menciptakanpenjualan produk. Penjualan produk akan terjadi apabila calon konsumenmelakukan keputusan pembelian terhadap produk tersebut. Keputusan pembelianadalah keputusan konsumen terhadap merek terpilih di antara kumpulan pilihanmerek-merek yang ada.

Dalam memilih produk untuk dikonsumsi, konsumen akan memilih yangterbaik diantara beberapa pilihan. Untuk memutuskan produk mana yang akandibeli di antara beberapa 


\section{Jurnal Ecobisma Vol. 4 No. 2 Juni 2017}

pilihan tersebut dipengaruhi oleh beberapa faktor.Menurut sejumlah penelitian, terdapat beberapa faktor yang mempengaruhikeputusan pembelian, salah satunya ialah kualitas produk.

Faktor lain yang mempengaruhi keputusan pembelian yakni harga. Hargaadalah sejumlah uang yang diperlukan untuk mendapatkan sejumlah kombinasidari barang beserta pelayanannya. Sedangkan, harga adalah pertukaran uang dengan barang atau jasadan waktu yang dikorbankan untuk menunggu memperoleh barang atau jasa.

Untuk menetapkan sebuah harga diperlukan strategi-strategi khusus agar hargadirasa cukup ideal oleh konsumen. Harga dirasa ideal bagi konsumen apabilakualitas produk sebanding dengan uang yang dikeluarkan untuk membeli produktersebut.

Adapun faktor lain yang mempengaruhi keputusan pembelian yakni lokasi.Strategi lokasi adalah salah satu faktor penting dalam perilaku konsumen,perusahaan harus memilih lokasi yang strategis dalam menempatkan usahabisnisnya di suatu kawasan atau daerah yang dekat dengan keramaian danaktivitas masyarakat.Dalam memulai bisnis, faktor lokasi merupakan salah satu faktor yangcukup penting, pengusaha akan melihat faktor lokasi apakah lokasi tersebut ramaioleh penduduk atau tidak. Lokasi adalah komitmen sumberdaya jangka panjang yang mempengaruhi fleksibilitas toko tersebut, kemudianlokasi akan mempengaruhi pertumbuhan atau keberlangsungan sebuah toko dimasa depan, selain itu lingkungan dapat berubah setiap waktu tergantung dengannilai lokasi tersebut

Kelurahan Perdameanmemiliki tingkat pertumbuhan yang tinggi karena meningkatnya aglomerasi perumahan di daerah ini. Adanya infrastrukturjalan dan akses yang baik dan dapat menunjang pertumbuhanperumahan dan aktivitas perdagangan. Banyak fasilitas perdagangan danperumahan yang muncul di daerah Kelurahan Perdamean seperti Ada Swalayan danberbagai perumahan. Daerah Kelurahan Perdameanmemiliki tingkat kepadatanpenduduk dan dikelilingidengan institusi pendidikan dari tingkat SD hingga SMA, hal ini menjadikan daerah Perdameansebagaiwilayah yang potensial untuk didirikan bisnis kuliner. Bisnis kuliner memangmenjadi favorit bagi banyak pelaku bisnis, mulai dari jenis cafe, rumah makansederhana, hingga warteg dapat dijumpai di sepanjang wilayah Perdamean.

Agar produknya menarik konsumen, pelaku bisnis melakukan strategidiferensiasi produk. Dalam merebut perhatian konsumen para pelaku usahamenciptakan produk yang kreatif dan terlihat berbeda agar menciptakandiferensiasi. Diferensiasi adalah usaha untuk membedakan diri dari pesaing,mereka harus semakin kreatif agar produknya lebih menarik konsumen.

Jajanan tradisional biasanya dibuat dengan cita rasa yang unik serta bentuk yang menarik. Contoh - contoh jajan tradisional yang sering ditemui di Kelurahan Perdameanadalah kue lapis, klepon, lemper, pastel, dan lain-lain. Saat ini keberadaan jajanan tradisional lebih banyak ditemui di pasar, di tepi jalan, dan acara tertentu. Namun sekarang di beberapa pusat perbelanjaan juga sudah ada yang menjual jajanan tradisional. Jajanan tradisional yang dijual di kelurahan Perdameanmerupakan ciri khas Indonesia dan juga makanan kecil khas sendiri tetapi keberadaannya mulai bergeser karena munculnya jajanan moderen. Hal tersebut menyebabkan masyarakat menjadi kurang mengenal jajanan tradisional khususnya di kalangan remaja. Seiring dengan berjalannya waktu dan berkembangnya zaman, banyak bermunculan pula moderen yang lebih menarik di mata remaja sehingga lebih memilih untuk mengkonsumsi jajanan modern daripada jajanan tradisional.

Ada beberapa alasan mengapa jajanan tradisional kurang diminati, di antaranya adalah komposisi bahan dan kandungan gizi tidak standar, waktu pengolahan lama, cara pengolahan tidak bersih atau tidak higienis, penyajian dan pengemasan kurang menarik, lokasi penyajian kurang nyaman, umur simpan pendek, dan cita rasa kurang sesuai dengan selera generasi muda. 
Berdasarkan pada uraian latar belakang masalah yang terjadi di atas maka dapat diajukan sebuah penelitian dengan judul Faktor-faktor yang mempengaruhi konsumen dalam pembelian makanan jajanan tradisional di Kelurahan Perdamean.

\section{Perumusan masalah}

Adapun rumusan masalah dalam penelitian ini adalah sebagai berikut;

1. Apakah harga berpengaruh signifikan terhadap pembelian makanan jajanan tradisional di Kelurahan Perdamean?

2. Apakah lokasi berpengaruh signifikan terhadap pembelian makanan jajanan tradisional di Kelurahan Perdamean?

3. Apakah harga dan lokasi berpengaruh signifikan terhadap pembelian makanan jajanan tradisional di Kelurahan Perdamean?

\section{Tujuan penelitian}

Tujuan penelitian ini adalah :

1. Untuk mengetahuipengaruh harga terhadap pembelian makanan jajanan tradisional di Kelurahan Perdamean.

2. Untuk mengetahuipengaruh lokasi terhadap pembelian makanan jajanan tradisional di Kelurahan Perdamean.

3. Untuk mengetahuipengaruh harga dan lokasi terhadap pembelian makanan jajanan tradisional di Kelurahan Perdamean.

\section{Studi Literatur}

\section{Keputusan Pembelian}

Kotler dan Keller (2009:91) menyatakan bahwa keputusan pembelian adalahkeputusan konsumen mengenai preferensi terhadap kumpulan merek-merek.Menurut Setiadi (2010:77), inti dari pengambilan keputusan oleh konsumen adalahproses pengintegrasian dengan mengkombinasikan pengetahuan yang dimilikimengenai produk untuk mengevaluasi dua atau lebih alternatif untuk kemudiandipilih salah satu diantaranya.Kotler (2009:90) menyatakan bahwa setiap orang memiliki peran yang berbeda-bedadalam keputusan pembelian, antara lain:

1. Pengambil inisiatif (initiator)

Yakni orang yang pertama menyarankan atau memikirkan gagasan untukmembeli sebuah produk.

2. Orang yang mempengaruhi (influence)

Adalah orang yang pandangannya diperhitungkan dalam keputusan akhir

3. Pembuat keputusan (decider)

Yakni seorang yang menentukan keputusan terhadap produk yang akandibeli, cara pembayaran dan tempat membeli produk.

4. Pembeli (buyer)

Adalah orang yang melakukan pembelian.

5. Pemakai (user)

Yakni satu atau beberapa orang yang memakai suatu produk atau jasa.

Adapun indikator keputusan pembelian menurut Kotler (2009:114) yaitu:

1. Menjatuhkan pilihan pada produk yang terbaik,

2. Pengambilan keputusan dilakukan secara sadar, rasional, obyektif dan terencana,

3. Kesetiaan terhadap produk 


\section{Harga}

Harga menurut Kotler (2009:105) adalah sejumlah uang yang harus dibayarkanoleh konsumen untuk mendapatkan produk. Penetapan harga yang tepat akanmemberikan keuntungan bagi perusahaan, hal ini penting agar harga yangditetapkan cukup untuk menutupi biaya-biaya produksi serta memberikan untungkepada perusahaan namun di sisi lain juga dirasa pas oleh konsumen, pas artinyacocok oleh kualitas produk yang diberikan.

Menurut Kotler dan Amstrong (2009:278), indikator yangmencirikan harga yaitu: ketersediaan lebel haraga, kesesuaian harga dengan kualitasproduk, harga yang kompetitif dibanding produk lain sejenis, keterjangkauan harga produk dan kesesuaian harga dengan manfaat produk.

\section{Lokasi}

Lokasi menurut Swastha (2008:101) adalah letak toko atau pengecer di daerahyang strategis sehingga dapat memaksimalkan laba. Konsumen dalam memenuhikebutuhannya akan memilih lokasi yang dianggap mudah dijangkau. Fitzsimmons (dikutip oleh Tjiptono, 2007:89) menyatakan bahwa lokasi berpengaruh terhadapdimensi-dimensi strategik, yakni fleksibilitas, competitivepositioning,manajemen permintaan, dan focusstrategic.

Adapun menurut Tjiptono dan Chandra (2007:90) menyatakan bahwapemilihan lokasi memerlukan pertimbangan-pertimbangan seperti:

\section{Akses}

Kemudahan menjangkau lokasi dan sarana transportasi yang memadaiakan memberikan pengalaman akses yang baik kepada konsumen.

2. Visabilitas

Apabila sebuah toko berada pada lokasi yang mudah terlihat tentunyaini menjadi keuntungan tersendiri bagi toko tersebut karena akanmudah dikenali oleh konsumen.

3. Lalu lintas

Wilayah yang dilalui oleh banyak orang dapat memberikan peluangsemakin dikenalnya toko tersebut dan berpotensi adanya impulse buying, namun jika wilayahnya terlalu padat dan terdapat kemacetanlalu lintas maka akan berpotensi menciptakan hambatan kemudahanakses terhadap toko tersebut.

4. Tempat Parkir

Fasilitas tempat parkir yang luas dan aman akan menambah preferensikonsumen untuk memilih toko tersebut.

5. Ekspansi

Yaitu adanya area yang bisa digunakan untuk perluasan usaha dikemudian hari.

6. Lingkungan

Yakni daerah sekitar yang mendukung jasa yang ditawarkan.

7. Kompetisi

Dalam hal ini adalah lokasi pesaing. Pemilihan lokasi suatu usahaperlu mempertimbangkan jarak lokasi dengan pesaing.

8. Peraturan Pemerintah

Peraturan ini berisi ketentuan mengenai syarat pendirian sebuah usaha.

Memilih lokasi yang baik adalah keputusan yang penting. Lamb (2007:104)menyatakan bahwa lokasi adalah komitmen sumber daya jangka panjang yangmempengaruhi fleksibilitas toko tersebut, kemudian lokasi akan mempengaruhipertumbuhan atau keberlangsungan sebuah toko di masa depan, selain itulingkungan dapat berubah setiap waktu tergantung dengan nilai lokasi tersebut.

Indikator lokasi yang digunakan dalam penelitian ini yaitu (Akbar, 2011:45):

a) Arus lalulintas menuju lokasi lancar 
b) Tempat penjualan yang strategis dan mudah dijangkau

c) Situasi lingkungan warung yang aman

d) Dekat dengan pusat keramaian.

e) Tersedianya lahan parkir yang memadai.

\section{METODE PENELITIAN}

Menurut Sugiyono (2012:100) populasi adalah wilayah generalisasi yang terdiri atas objek atau subjek yang mempunyai kualitas dan karakteristik tertentu yang ditetapkan oleh peneliti untuk dipelajari kemudian ditarik kesimpulan. Pada penelitian ini populasinya adalah masyarakat Kelurahan Perdamean.

Menurut Sugiyono (2012:100), sampel adalah bagian dari jumlah dan karakteristik yang dimiliki oleh populasi tersebut. Penentuan jumlah sampel ditentukan dengan menggunakan beberapa metode antara lain dengan menggunakan rumus sebagai berikut Widiyanto (2008:120).

$n=\frac{Z^{2}}{4(\text { Moe })^{2}}$

$n=\frac{1,98^{2}}{4(0,1)^{2}}$

$=98,01=98$

Dimana :

$n:$ Jumlah sampel

$\mathrm{Z}$ : Tingkat keyakinan yang dibutuhkan dalam penentuan sampel $95 \%$ pada penentuan ini $\mathrm{Z}$ pada $\alpha=0,5$ adalah 1,98

Moe : Margin of Error, yaitu tingkat kesalahan maksimal yang dapat ditoreransi, ditentukan sebesar $10 \%$.

Dari hasil perhitungan sampel diatas maka jumlah sampel dalam penelitian ini sebanyak 98 responden.Data primer adalah data yang diambil langsung dari tempat dimana penelitiandilakukan berupa wawancara kepada masyarakat sertajawaban responden terhadap kuisioner yang berhubungan dengan penelitian.

\section{HASIL PENELITIAN}

\section{Analisis Regresi Linier berganda}

Metode statistik yang digunakan untuk menguji hipotesis adalah regresi linierberganda dengan bantuan perangkat lunakSPSS. Metode yang menghubungkan satuvariabel dependen dengan variabelindependen, sesuai hipotesis yang diuji dalampenelitian. Tabel berikut ini akan memperlihatkan hasil dari perhitungan untukanalisis regresi linier berganda dari 98 responden. 
Tabel 1. Regresi Linier Berganda

Coefficients $^{\mathrm{a}}$

\begin{tabular}{|c|c|c|c|c|c|}
\hline \multirow[t]{2}{*}{ Model } & \multicolumn{2}{|c|}{$\begin{array}{l}\text { Unstandardized } \\
\text { Coefficients }\end{array}$} & \multirow{2}{*}{$\begin{array}{c}\begin{array}{c}\text { Standardiz } \\
\text { ed } \\
\text { Coefficient } \\
\text { s }\end{array} \\
\text { Beta }\end{array}$} & \multirow[t]{2}{*}{$\mathrm{t}$} & \multirow[t]{2}{*}{ Sig. } \\
\hline & $\mathrm{B}$ & Std. Error & & & \\
\hline $\begin{array}{l}\text { (Consta } \\
\text { nt) }\end{array}$ & 4,445 & 2,037 & & 2,183 & 032 \\
\hline Harga & ,329 & ,095 & 269 & 3,470 & ,001 \\
\hline Lokasi & 493 & 068 & ,562 & 7,247 & ,000 \\
\hline
\end{tabular}

a. Dependent Variable: Keputusan pembelian

Sumber: Data primer; 2016

Dari hasil perhitungan diatas dapat dibuat sebuah model persamaan regresi linier berganda, yaitu sebagai berikut :

$$
\mathrm{Y}=4,445+0,329 \mathrm{X}_{1}+0,493 \mathrm{X}_{2}
$$

Persamaan tersebu dapat dijelaskan sebagai berikut:

a. Konstanta $\left(\alpha_{0}\right)$ bernilai 4,445 hal ini menunjukkan bahwa jika tidak ada pengaruh variabel harga dan lokasi, maka keputusan pembelian akan tetap ada sebesar 4,445, atau 44,45\% variabel harga dan lokasi mempengaruhi keputusan pembelian.

b. Koefisien regresi $X_{1}\left(\alpha_{1}\right)$ sebesar 0,329 artinya bahwa setiap peningkatan sebesar satu satuan pada variabel harga, maka keputusan pembelian akan meningkat sebesar 0,329 satuan. Hal tersebut menunjukkan bahwa faktor harga berpengaruh positif terhadap keputusan pembelian

c. Koefisien regresi $X_{2}\left(\alpha_{2}\right)$ sebesar 0,493artinya bahwa setiap peningkatan sebesar satu satuan pada variabel lokasi, maka keputusan pembelian akan meningkat sebesar 0,493. satuan. Hal tersebut menunjukkan bahwa faktor lokasi berpengaruh positif terhadap keputusan pembelian.

Dengan demikian berdasarkan analisis regresi linier berganda dapat disimpulkan bahwa keputusan pembelian dipengaruhi oleh faktor harga dan lokasi.

\section{Uji Validitas}

Menurut sugiono (2012:89), instrumen yang valid berarti alat ukur yang digunakan untuk mendapatkan data (mengukur) itu valid.valid berarti instrumen tersebut dapat digunakan untuk mengukur apa yang seharusnya diukur dan data-data yang diperoleh dengan mengunakan instrumen dapat menjawab suatu penelitian.Uji validitas digunakan untuk mengukur sah atau valid tidaknya suatukuesioner. Uji validitas dilakukan denganmembandingkan nilai $r$ hitung dengan $r$ tabel.Jika $r$ hitung yang merupakan nilai correcteditem - total correlation $=\mathrm{r}$ tabel maka alatukur yang digunakan dinyatakan valid dansebaliknya, jika $r$ hitung $<\mathrm{r}$ tabel maka alatukur yang digunakan tidak valid. Nilai $r$ tabeldiperoleh dengan persamaan $\mathrm{N}-2=98-3=$ 95(lihat tabel $\mathrm{r}$ dengan $\mathrm{df} 95)=0,202$. Nilai rhitung dalam uji ini adalah pearson Correlationantara item dengan skor pertanyaan. Diketahui untuk nilai dalam penelitianini adalah sebesar $r$ hitung lebih besar dari $r$ tabel $(0,202)$. Artinya adalah seluruh item pernyataan dinyatakan valid. 
Tabel 2. Uji Validitas

\begin{tabular}{cllll} 
Dimensi & Indikator & R hitung & $\begin{array}{l}\mathrm{R} \\
\text { tabel }\end{array}$ & Kesimpulan \\
& Item 1 & 0,662 & 0,202 & Valid \\
\multirow{3}{*}{ Harga } & Item 2 & 0,694 & 0,202 & Valid \\
& Item 3 & 0,664 & 0,202 & Valid \\
& Item 4 & 0,649 & 0,202 & Valid \\
& Item 5 & 0,675 & 0,202 & Valid \\
& Item 1 & 0,519 & 0,202 & Valid \\
Lokasi & Item 2 & 0,765 & 0,202 & Valid \\
& Item 3 & 0,547 & 0,202 & Valid \\
& Item 4 & 0,656 & 0,202 & Valid \\
& Item 5 & 0,620 & 0,202 & Valid \\
& Item 1 & 0,535 & 0,202 & Valid \\
Keputusan & Item 2 & 0,697 & 0,202 & Valid \\
pembelian & Item 3 & 0,624 & 0,202 & Valid \\
& Item 4 & 0,741 & 0,202 & Valid \\
& Item 5 & 0,575 & 0,202 & Valid
\end{tabular}

Sumber: Data primer; 2016

Dari tabel pengujian validitas dengan menggunakan SPSS diatas dapat dilihat bahwasemua item pernyataan pada variabel harga $\left(\mathrm{X}_{1}\right)$, lokasi $\left(\mathrm{X}_{2}\right)$ dan keputusan pembelian(Y) memiliki nilai corrected item totalcorrelation atau $\mathrm{r}$ hitung lebih besar dari rtabel sebesar 0,176 yang artinya dari masing-masing 5 item pernyataan pada variabelharga $\left(\mathrm{X}_{1}\right)$, lokasi $\left(\mathrm{X}_{2}\right)$ dan keputusan pembelian(Y) dinyatakan valid dan layak digunakan.

\section{Uji Reabilitas}

Selain uji validitas, dilakukan juga ujireliabilitas kepada keseluruhan sampel yangberjumlah 98 responden. Uji reliabilitasdilakukan pada butir-butir pernyataan yang telah valid. Teknik untuk menguji reliabilitas instrument yaitu dengan menggunakan metode cronbach's alpha dimana variabel tersebut akan dinyatakan reliable dengan ketentuan. Apabila nilainya kurang dari 0,6 adalah kurang baik.

1. Apabila nilainya 0,7 dapat diterima

2. Apabila nilainya diatas 0,8 adalah baik

Adapun hasil uji reliabilitas terhadap 98 responden dapat dilihat pada tabel berikut ini 


\section{Tabel 3. Uji Reliabilitas}

\begin{tabular}{lccc}
\multicolumn{1}{c}{ Indikator } & $\begin{array}{c}\text { Cronbach's } \\
\text { Alpha }\end{array}$ & Nilai kritis & Kesimpulan \\
& 0,691 & 0,6 & Reliabel \\
Harga & 0,807 & 0,6 & Reliabel \\
Lokasi & 0,794 & 0,6 & Reliabel
\end{tabular}

Sumber: Data Olahan SPSS, 2016

Pada tabel diatas terlihat bahwa variabel harga $\left(\mathrm{X}_{1}\right)$, lokasi $\left(\mathrm{X}_{2}\right)$ dan keputusan pembelian(Y) memiliki nilai cronbach's alpha diatas 0,6 . Untuk variabel harga $\left(\mathrm{X}_{1}\right)$ nilai cronbach's alpha sebesar 0,691, lokasi $\left(\mathrm{X}_{2}\right)$ nilai cronbach's alpha sebesar 0,807, sedangkan untuk keputusan pembelian (Y) nilai cronbach's alpha sebesar 0,827. Hal ini bahwa variabel X dan Y tersebut telah memenuhi kriteria nilai batas dan dapat dinyatakan reliable serta layak untuk disebarkan kepada responden guna penelitian.

\section{Pengujian Hipotesis Koefisien Regresi Koefisien Determinasi}

Koefisien determinasi $\left(\mathrm{R}^{2}\right)$ adalah sebuah koefisien yang menunjukkanpersentase pengaruh semua variabel independen terhadap variabel dependen. Persentase tersebut menunjukkan seberapa besar variabel independen (harga dan lokasi)dapat menjelaskan variabel dependennya(keputusan pembelian). Semakinbesar koefisien determinasinya, semakin baikvariabel dependen dalam menjelaskan variabelindependennya. Dengan demikian persamaanregresi yang dihasilkan baik untuk mengestimasi nilai variabel dependen.Untuk mengetahui besarnya pengaruh variabel independen dapat dilihat pada tabel berikut ini:

\section{Tabel 4.Koefisien Determinasi}

Model Summary ${ }^{\mathrm{b}}$

\begin{tabular}{|l|r|r|r|r|}
\hline Model & \multicolumn{1}{|c|}{$\mathrm{R}$} & $\mathrm{R}$ Square & \multicolumn{1}{|c|}{$\begin{array}{c}\text { Adjusted R } \\
\text { Square }\end{array}$} & $\begin{array}{r}\text { Std. Error of } \\
\text { the Estimate }\end{array}$ \\
\hline 1 &, $688^{\mathrm{a}}$ &, 773 &, 462 & 1,269 \\
\hline
\end{tabular}

a. Predictors: (Constant), Lokasi, Harga

b. Dependent Variable: Keputusan pembelian

Berdasarkan hasil perhitungan didapat nilai koefisien determinasi sebesar 0,773. Artinya $77,3 \%$ variabel terikat dijelaskan oleh variable bebas dan sisanya dijelaskan oleh variabel lain diluar variabel yang digunakan.Dengan demikian model regresi linier berganda ini layak dipakai dalam penellitian, karena sebagian besar variabel terikat dijelaskan oleh variabel-variabel bebas yang digunakan dalam model.

\section{Uji Signifikan Individu (Uji t)}

Uji t dilakukan untuk mengetahui masing-masing variabel bebas terhadapvariabel terikat secara parsial atau individual.Untuk menjawab hipotesis yang telahdiajukan, maka dilakukan uji t. Adapun rumushipotesis statistiknya : 
Ho : harga $\left(\mathrm{X}_{1}\right)$ danlokasi $\left(\mathrm{X}_{2}\right)$ tidak ada hubungan dengan keputusan pembelian $\mathrm{Ha}$ : harga $\left(\mathrm{X}_{1}\right)$ danlokasi $\left(\mathrm{X}_{2}\right)$ ada hubungan dengan keputusan pembelian

Dengan kriteria pengujian :

Jika $t$ hitung $<\mathrm{t}$ tabel maka Ho diterima dan Ha ditolak

Jika t hitung $>\mathrm{t}$ tabel maka Ho ditolakdan Ha diterima

Uji t dilakukan denganmembandingkan thitung dengan tabel padataraf signifikan $0,05 / 2=0.025$

dengan derajatkebebasan $\mathrm{T}$ tabel $=\mathrm{n}-\mathrm{k}-1$ : alpha/ $2=98-3-1: 0,05 / 2=94: 0,025=1,989$

Keterangan : $\mathrm{n}$ : jumlah, $\mathrm{K}$ : jumlah variabel bebas, 1 : konstan

1. Hasil perhitungan diperoleh nilai t hitung $(3,470)>$ dari t tabel $(1,989)$ maka Ho ditolak dan Ha diterima, sehingga variabel harga berpengaruh secara signifikan terhadap pembelian makanan jajanan tradisional di Kelurahan Perdamean.

2. Hasil perhitungan diperoleh nilai t hitung $(7,247)>$ dari t tabel $(1,989)$ maka Ho ditolak dan Ha diterima, sehingga variabel lokasi berpengaruh secara signifikan terhadap pembelian makanan jajanan tradisional di Kelurahan Perdamean.

\section{DAFTAR PUSTAKA}

Akbar, Panji, A. 2011. Analisis Pengaruh Kualitas Pelayanan, Harga, dan Lokasi Terhadap Keputusan Pembelian Sepeda Motor Honda (Study Kasu Pada Dealer Sepeda Motor Honda Di Kota Banjarnegara): skripsi. Fakultas Ekonomi Universitas Diponegoro: Semarang.

Basu Swastha,dan Sukotjo, 2008, Manajemen Pemasaran Modern, Liberty: Yogyakarta

Felicia Linarda, Sindy (2013), Perilaku masyarakat Surabaya terhadap keputusan pembelian makanan tradisional Indonesia ditinjau dari faktor eksternal \& internal

Fandy Tjiptono dan Gregorius Chandra (2007). Manajemen Kualitas Jasa. Yogyakarta, Andi

Imam Ghozali, (2009), Aplikasi Analisis Multivariat dengan Program SPSS, Badan Penerbit Universitas Diponegoro, Semarang.

Ibnu, Widiyanto, 2008. Pointers : Metodologi Penelitian. Semarang: BP Undip

Jesslyn Santoso (2013), Pengaruh budaya, sub budaya, kelas sosial, dan persepsi kualitas terhadap perilaku keputusan pembelian kue tradisional oleh mahasiswi di Surabaya

Kotler, Philip; Armstrong, Garry, 2009. Prinsip-prinsip Pemasaran,Jilid 1, Erlangga, Jakarta.

Lamb, Charles. W. et.al. 2007. Pemasaran. Buku I Edisi Pertama. Penerbit Salemba Empat. Jakarta

Mariska Deasy Paramitha (2015), Analisis pengaruh kualitas produk, harga, dan lokasi terhadap keputusan pembelian(Studi Pada Konsumen Mie Nges-Nges BanyumanikSemarang).

Philip Kotler \& Kevin Lane Keller,2009, Manajemenpemasaran,Edisi 13 Jilid 1. Jakarta.

RambatLupiyoadi, 2007,Manajemen Pemasaran Jasa, Salemba Empat, Jakarta

Setiadi, Nugroho J. 2010, Perilaku Konsumen. Kencana. Jakarta.

Setiaji, Bambang. 2006. Panduan Riset dengan Pendekatan Kuantitatif. Surakarta: Muhammadiyah University Press.

Sugiyono, 2012, Metode Penelitian Bisnis, Penerbit CV AlphaBetha, Bandung

Stanton, William J. 2007. Prinsip Pemasaran. Alih Bahasa oleh Sadu Sundaru. Jakarta : Erlangga.

Tjiptono, Fandy. 2007.Strategi Pemasaran (Edisi II). Yogjakarta: Penerbit Andi 